\title{
A Re-Examination of the Capital Structure Theory: Evidence from Chinese Listed Companies
}

\author{
Liang Guo ${ }^{1 *}$, Yu Liu ${ }^{1}$, Ya Dai $^{2}$, Hongxian Zhang ${ }^{3}$ \\ ${ }^{1}$ Department of Accounting and Finance, Jack H. Brown College of Business and Public Administration, California \\ State University, San Bernardino, CA, USA \\ ${ }^{2}$ College of Business, Metropolitan State University of Denver, Denver, CO, USA \\ ${ }^{3}$ College of Arts, Sciences, and Business, Missouri University of Science and Technology, Rolla, MO, USA \\ Email: *lguo@csusb.edu
}

How to cite this paper: Guo, L., Liu, Y., Dai, Y. and Zhang, H.X. (2018) A Re-Examination of the Capital Structure Theory: Evidence from Chinese Listed Companies. Theoretical Economics Letters, 8, 935-959. https://doi.org/10.4236/tel.2018.85066

Received: October 26, 2017

Accepted: April 9, 2018

Published: April 12, 2018

Copyright (c) 2018 by authors and Scientific Research Publishing Inc. This work is licensed under the Creative Commons Attribution International License (CC BY 4.0).

http://creativecommons.org/licenses/by/4.0/

(c) (i) Open Access

\begin{abstract}
In this study, we examine whether and to what extent the main stream capital structure theories developed in Western countries apply to Chinese listed companies during its most recent transition period after year 2000. Specifically, we examine a variety of trade-off and pecking order models and compare their performance by nesting these two different models in the same regression. Using market-based leverage data from 1057 non-financial Chinese listed firms during the period from 2000 to 2011, we present empirical evidence indicating that: firstly, equity tracks the financing deficit better than debt in Chinese firms, which is not consistent with the pecking order theory. Secondly, Chinese firms seem to be more sensitive in expanding debt for meeting their financing needs than in using surplus for retiring debt. Thirdly, Chinese firms have an optimal market-based leverage ratio. Both the partial adjustment and error correction models suggest that Chinese firms adjust towards target leverage slowly before 2006 . However, after 2006, they accelerate their leverage adjustments at a speed as fast as that documented in the developed markets. The increasing adjustment speeds are attributed to the shrinking transaction costs and agency costs caused by recent currency and share-split structure reforms. Overall the trade-off theory works better than the pecking order theory in explaining Chinese firms' capital structure. Chinese companies' financing behaviors are becoming more akin to those in the developed market with increasing integration and financial liberalization.
\end{abstract}

\section{Keywords}

Capital Structure Theory, China's Structural Reforms, Optimal Leverage 


\section{Introduction}

The financing choice is one of the most important decisions made by corporate managers. However, capital structure policy remains as one of the most puzzling but interesting topics in finance research, particularly for transition emerging countries. The major purpose of this study is to reexamine capital structure decisions of companies in the largest emerging economy, China. We intend to extend our knowledge of how structural reforms implemented in China during the last decade impact financing behaviors of its publicly-listed nonfinancial companies and to what extent their financing behaviors are in line with the main stream capital structure theories, namely the trade-off and pecking order theories.

Both trade-off and pecking order theories explain capital structure by examining the impact of market frictions. The former theory emphasizes costs of bankruptcy, financial distress and agency problems and predicts that trade-offs of those costs against benefits of debt (including tax advantage and reducing free cash flow agency costs) imply an optimal capital structure in firms. In contrast, the pecking order theory focuses on the cost of imperfect information and predicts no well-defined target capital structure. Instead, it suggests that information asymmetries that exist between the managers of a firm and potential investors cause adverse selection problems, which in turn lead to a financing hierarchy where internal financing is preferred over external financing and debt is preferred over equity. These two theories have intrigued much interest of researchers for the last few decades and an enormous body of empirical studies has been developed to examine the effectiveness in their explanations, with the majority being conducted in the context of developed markets. ${ }^{1}$ However, capital structure issues in transition economy have not been widely investigated and have still remained ambiguous.

It is important for academics, financial managers, and policy makers to examine financing practices of publicly listed companies in transition countries and compare them to those in developed markets. This will offer new insights about how growing market forces and financial privatization transform the dynamics of companies' capital structure choices. In transition markets, government and state-owned commercial banks play a considerable role in the financial system and capital allocation, and this role implies a structural imbalance and market inefficiency in the economy. Very recently these transition countries have been implementing a series of structural reforms to shift towards the free market economy to improve the efficiency and competitiveness of the economy. This kind of structural transformation yields a big impact on firms' financing

${ }^{1}$ See, e.g., [1] [2] and [3]. 
behaviors and therefore allows us to examine the impact of institutional changes on capital structure choices in transition economies. Undoubtedly, China has become the most successful transitional economy in the last decade and emerged as a major world economic power. In particular, since entering the new Millennium, China has intensified its efforts to enhance the openness of its economy and liberalized its financial system by establishing a series of new structure reforms, and gained significant achievements. ${ }^{2}$ Hence, China offers an ideal ground for testing the explanatory power of the two capital structure theories and examining their practical implications for transition economies.

Although several studies investigate capital structure of Chinese listed companies (e.g., [4]), we are far from reaching a well-accepted conclusion, prompting a necessity to extend our knowledge of Chinese financing behaviors using novel empirical models and more recent data. Specifically, main motivations for this study are as follows. First, most of existing studies testing the trade-off theory in Chinese markets assume that the observed leverage ratio is optimal and examine the determinants of optimal capital structure using static models (e.g., [5] [6], and [7]). [4] argued that the presence of adjustment costs may prevent firms from quickly moving back to their optimal leverage levels, causing actual (observed) leverage ratios to differ from the optimal levels. They follow [8] and employ a dynamic trade-off model (a.k.a., the partial adjustment model), which allows for a gradual adjustment of the leverage ratio toward the target level. [4] showed that Chinese firms adjust their leverage towards the target at a very slow rate of 0.185 during the period from 1999 to 2004, which is far slower than the speed with which firms in the developed countries undertake leverage adjustment as documented by [8] [9] [10] [11]. ${ }^{3}$ However, the aforementioned empirical studies testing the trade-off theory in Chinese markets focus on periods before the completion of the recent share structure reform. ${ }^{4}$ [12] argued the share structure reform that was launched in 2005 and scheduled to be completed in 2006 has significantly changed corporate behaviors in China. Incorporating the post-reform data gives us an opportunity to examine whether the explanatory power of capital structure theories is enhanced with the improvement in market efficiency and privatization.

Second, the existing empirical studies in Chinese market ignore the fact that costs of adjusting leverage may also change as firms move toward target leverage (See, e.g., [11] and [13]). Correspondingly, the long term effect of the target leverage ratio on the current leverage ratio, which may offer us new insights on their financing practices, has never been tested for Chinese listed companies. Last but not least, previous empirical studies in the Chinese market only test the pecking order or trade-off theories separately. Recent research nests both theo-

${ }^{2}$ For example, the share structure reform implemented in 2006 has significantly changed investors' ability to trade corporate equities and improved market efficiency.

${ }^{3}$ It is well documented in the literature that firms in the developed markets (e.g. US, UK, German, French, Spain, etc.) adjust toward their target leverage at a speed of more than 0.3 .

${ }^{4}$ The existing empirical studies that test Chinese listed companies have been based on the data before year 2005 . 
ries in a single specification and examines them simultaneously (e.g., [3] [8] [9] [11] [14]). This novel empirical methodology allows us to examine both theories jointly and decide which one is better in explaining the market-based capital structure in Chinese listed firms. In this study we employ the market-based leverage ratios in our empirical analysis.

The remainder of the study is organized as follows. Next section reviews Chinese recent structural reforms. Section 2 provides a selected literature review. Section 3 describes the main data sources and provides descriptive statistics on capital structure variables. Section 4 presents the empirical methodology and test results of the pecking-order theory. Section 5 tests the static trade-off models and examines the determinants of capital structure of Chinese listed firms. Section 6 and 7 discuss the methodology and test results of two different types of the dynamic trade-off models, including the partial adjustment models and error correction models. Conclusions and empirical implications are provided in Section 8.

\section{Overview of Recent China's Economic Structural Reforms}

China launched its historical transition from a planned to a market economic system in 1978 and began to privatize the public sectors and state-owned industries in the late 1980s and 1990s. However, China, like other transition developing countries, relied on a state-supported route for economic development in the very beginning with a relatively small private corporate sector. Most of Chinese listed companies had a large percentage of non-tradable state shares and non-tradable legal person shares ${ }^{5}$ until very recently. The significant roles of the government and the state ownership with excessive government involvement in the financial system adversely hampered the healthy growth of the capital markets and entire economy. As it entered into the new century, China intensified its efforts to increase the openness of the economy and sped up its privatization of the state-owned enterprises. For example, as a milestone in its reform and opening-up policies, China joined the World Trade Organization (WTO) in December, 2001 and began to strengthen its integration with the international economy. As another sign that China is loosening its tight grip over the economy, the government began to gradually reform its currency policy in 2005 by increasing the flexibility of the exchange rates. The increasing integration with the measures that have been taken to improve financial liberalization (e.g. the introduction of Qualified Foreign Institutional Investor (QFII) program to lower entry barriers for foreign investors) brings new challenges and opportunities for Chinese firms to compete in the international market and thus, make it more urgent for their business managers to seek optimal financing plans for their investment activities in order to sharpen their competitiveness in the global markets.

${ }^{8}$ Those are shares held by state-owned enterprises, institutions, authorized social groups or other entities that have been granted "legal person" status. 
The most significant reform is the share structure reform launched in 2005 to grant legitimate trading rights to the non-circulating state-owned shares. Over $70 \%$ of total shares in Chinese stock market were non-tradable in 2004. The 2005 split-share reform mandated a conversion of the non-tradable shares to tradable shares. [15] and [16] documented that most of Chinese listed firms completed the reform during 2005-2006 and only $2 \%$ of the firms failed to comply the deadline of the December 2006 (most of those complied in January 2007). It opened up the door to China's secondary privatization. Overall, the Chinese economic transformations and the extensive privatization that have unfolded since year 2000 offered business managers more flexibility in determining the capital structure of the companies and therefore, significantly changed their corporate financing behaviors.

The share structure reform significantly increased the trading activities in the secondary stock market, and improved the liquidity and depth of the Chinese stock market. On the one hand, as argued by [15], the increase in secondary market liquidity makes it easier and cheaper for firms to obtain funding from the primary equity market, and potentially reduces the transaction (i.e. issuing or repurchase) costs of equity. This change in transaction costs due to the reform provides a perfect setting to test partial adjustment model. On the other hand, the increased trading volume and transactions may convey more information about firms' prospects (see, e.g., [17]) and potentially improve the transparency of financial market, which could change the driving force of the pecking-order behavior of corporate financing, namely the asymmetric information problems. Hence, China's economic transformation and privatization process provide an ideal ground for examining the explanatory power of capital structure theories. We hypothesize that the financing practices of Chinese listed firms during last decade were akin to those displayed in the developed markets and were more consistent with theoretical predictions.

\section{Literature Review}

Early empirical capital structure research has concentrated on testing implications of two traditional theories: the static tradeoff theory (see, e.g., [2]) and the pecking-order theory (see, e.g., [1]). But the empirical results are far from conclusive. For example, [9] and [18] provided evidence supporting the pecking order theory, while Frank and Goyal [3] and [19] provided evidence against the pecking order theory. Literature on the static trade-off theory also provided mixed results (see, e.g., [20] [21] and [22]). Recently, researchers have recognized the potential for incomplete adjustment (i.e., the partial adjustment), which has moved the literature toward the test of the dynamic tradeoff model (see, e.g., [8] [11] [23] [24], and [25]).

It is also worthy to mention that most studies of capital structure have used the data from developed countries with a few exceptions. [26] studied capital structure determinants of firms in 10 developing countries and find both simi- 
larities and differences across countries. [27] examined 23 emerging market countries and find little support for the pecking order theory. China is the largest developing and transition economy, and the second-largest economy in the world, yet only a limited number of studies on capital structure have examined the Chinese market.

Studies of capital structures of Chinese companies have been focused on tests of static trade-off model. [6] examined a broad dataset of over 1200 Chinese listed companies during a period 1994-2003 and regress different leverage measures on a list of explanatory variables. They find that a static trade-off model can explain the capital structure decision of Chinese companies better than the pecking order theory. [5] examined the determinants of capital structure of 88 large Chinese listed companies during the period 1995-2000 and finds that neither theory provides a convincing explanation of the financing behavior of Chinese companies. [28] looked at the top 50 listed companies published by the People's Daily for the period 2001-2003 and investigate the determinants of corporate leverage and the determinants of corporate investment. Their empirical evidence is in favor of the pecking order hypothesis.

More recent studies of capital structure of Chinese companies have moved to test the dynamic trade-off model ([8]) and to more directly test the pecking order model ([9]). Following the Shyam-Sunder and Myers model, [29] studied 422 Chinese companies for the accounting year of 2004 and find that only big companies in China follow the pecking order theory, while small and medium companies don't follow the pecking order theory. [30] also used the Shyam-Sunder and Myers model, but they examine capital financing behavior of a much larger number of Chinese companies during the period 1994-2006 and find results similar to [29]. [4] is the first article testing the dynamic trade-off theory on Chinese listed firms. Their sample contains 650 Chinese listed non-financial firms from 1999 to 2004. They present that Chinese listed firms tend to adjust to their optimal leverage levels but the speed of adjustment to optimal levels is very slow.

Overall, previous studies have offered some good insights into financing behaviors of Chinese listed firms. However, none of these studies have examined possible changes in financing behaviors of Chinese firms caused by the structural reforms unfolded during the last decade, nor have those studies nested the dynamic trade-off model and the pecking-order model in the single specification. Moreover, none of these studies have used an error correction model. Following our recent article (see, e.g., [31]), in this study we use a market-based measure of leverage instead of book leverage and we examine the impact of the recent China's economic structural reforms on the financing behavior of its listed firms. This is also consistent with the trade-off view and is adopted in many previous empirical studies (e.g., [22] and [32]). Different from previous literature, our study provides a new insight regarding the impact of China's recent economic structural reforms on the choices of the market-based leverage ratios. 


\section{Data and Descriptive Summary of Variables}

The data used in this study cover all non-financial listed firms in China during the period 2000-2011. The data are obtained from the China Stock Market and Accounting Research Database (CSMAR) and Bloomberg. We remove all firm-year observations with negative total liabilities/assets or negative revenues. We will use lagged variables as instruments in the difference GMM and system GMM model and, hence, we only retain firms that have 5 or more years of observations. Our final sample is an unbalanced panel with 12,132 firm-year observations for 1057 firms over the period 2000-2011 ${ }^{6}$.

Table 1 presents the descriptive statistics of variables of primary interest in Table 1. Summary statistics of capital structure variables.

\begin{tabular}{|c|c|c|c|c|c|c|c|}
\hline \multicolumn{8}{|c|}{ Panel A. Full Sample } \\
\hline & Obs & Mean & Median & $\begin{array}{l}\text { Std. } \\
\text { Dev. }\end{array}$ & Min & Max & \\
\hline Leverage & 12132 & 0.499 & 0.503 & 0.190 & 0.083 & 1.03 & \\
\hline Tangibility & 12132 & 0.290 & 0.261 & 0.183 & -0.206 & 0.971 & \\
\hline Non-Debt Tax Shields (NOT) & 12132 & 0.024 & 0.021 & 0.019 & -0.034 & 0.817 & \\
\hline Profitability & 12132 & 0.032 & 0.036 & 0.194 & -18.918 & 0.715 & \\
\hline Growth opportunity & 12132 & 0.511 & 0.504 & 0.388 & 0.010 & 27.928 & \\
\hline Firm Size & 12132 & 21.818 & 21.700 & 1.097 & 16.683 & 27.917 & \\
\hline Ownership & 12132 & 0.282 & 0.281 & 0.249 & 0.000 & 0.906 & \\
\hline \multirow[t]{4}{*}{ DEF } & 11844 & -0.004 & -0.009 & 0.252 & -19.268 & 2.979 & \\
\hline & \multicolumn{4}{|c|}{ Panel B: Subsamples } & & & \\
\hline & \multicolumn{3}{|c|}{ Year 2000-2006 } & & \multicolumn{3}{|c|}{ Year 2007-2011 } \\
\hline & Obs & Mean & Median & & Obs & Mean & Median \\
\hline Leverage & 7030 & 0.474 & 0.478 & & 5102 & 0.533 & 0.539 \\
\hline Tangibility & 7030 & 0.305 & 0.280 & & 5102 & 0.269 & 0.234 \\
\hline Non-Debt Tax Shields (NOT) & 7030 & 0.024 & 0.021 & & 5102 & 0.025 & 0.021 \\
\hline Profitability & 7030 & 0.036 & 0.038 & & 5102 & 0.027 & 0.033 \\
\hline Growth opportunity & 7030 & 0.478 & 0.480 & & 5102 & 0.556 & 0.540 \\
\hline Firm Size & 7030 & 21.602 & 21.504 & & 5102 & 22.115 & 21.999 \\
\hline Ownership & 7030 & 0.358 & 0.394 & & 5102 & 0.178 & 0.037 \\
\hline DEF & 6742 & -0.010 & -0.013 & & 5102 & 0.004 & -0.003 \\
\hline
\end{tabular}

Leverage is the ratio of total debt divided by total asset (market value). Tangibility is the ratio of fixed assets to total assets. NOT is the ratio of depreciation to total assets. Profitability is the ratio of EBITDA to total assets. Growth opportunity is defined as the market to book ratio. Firm Size is the log of total assets adjusted for price index. Ownership is the percentage of the shares owned by Chinese government or state agencies. $D E F$ is the cash flow deficit, and defined as follow: $D E F_{t}=$ Dividend payment for period $t+$ Capital expenditure for period $t+$ net increase in working capital for period $t+$ current portion of long-term debt at start of period $t$ - Operating cash flows ( after interest and taxes) for period $t$. It is scaled by total assets.

${ }^{6}$ We employed STATA to conduct the empirical analysis throughout this article. 
our empirical analysis. Panel A and Panel B reports the descriptive statistics for the full sample and sub-periods samples, respectively. After the structural reforms, the state government ownership significantly decreased, the mean state ownership declined to $17.8 \%$ from $35.8 \%$, and the median declined to $3.7 \%$ from $39.4 \%$. Another notable difference between Pre and Post-reform is that Chinese companies used more debt after the reform and therefore have higher leverage ratio, compared the mean leverage of $53.3 \%$ for the Post-reform period with $47.4 \%$ for the Pre-reform. At the same time, firms have less tangible assets in the Post-reform period.

\section{Testing Trade-Off Theory}

In their pioneering works on capital structure theory, Modigliani and Miller $(1958,1963)$ argue that a firm can maximize its value in a perfect capital market by using as much debt as possible. However, as documented by [2] [33] [34], and [35], the presence of bankruptcy and agency costs of debt prevents the unlimited use of debt and forces firms to trade off the costs and benefits of debt (i.e., tax savings and the reduction in the agency costs of free cash flow). Therefore, the trade-off theory predicts a well-defined optimal capital structure, chosen at the point where the marginal cost of debt equals to its marginal benefit.

The common approach has been to examine the determinants of optimal leverage ratio by regressing the observed leverage ratio against a number of explanatory variables. We follow the literature ([32] [36] and [37],) and consider the six frequently adopted determinants of leverage: profitability (Prof), firm size (Size), non-debt tax shields (NOT), growth opportunities (Growth), tangibility (Tang), and state ownership (Ownership).

$$
\begin{aligned}
\text { Debt }_{i t}= & a+b_{1} \text { Size }_{i t}+b_{2} \text { Prof }_{i t}+b_{3} \text { Growth }_{i t}+b_{4} \text { Tang }_{i t} \\
& +b_{5} \text { NOT }_{i t}+b_{6} \text { Ownership }_{i t}+\varepsilon_{i t}
\end{aligned}
$$

Consistent with the previous literature on Chinese listed firms ([6]), empirical results presented in Table 2 show that the determinants of optimal capital structure in China are generally similar to those documented for both developed countries and other developing countries. Below we discuss the effects of each determinant.

Firm size: The trade-off theory suggests that small firms tend to face high financial stress, agency costs, and transaction costs, therefore may rely less on debt financing while pecking order theory as suggested in [19] predicts that small firms are more vulnerable to informational asymmetries and adverse selection problems, thus it may be more costly for them to access to the stock market. Our results show that the coefficients on firm size are significantly positive, with slightly higher magnitude for the more recent sample period. This finding is consistent with the prediction of the trade-off theory from the previous evidence on Chinese companies ([6]).

Profitability: The trade-off theory predicts a positive relation between profitability and leverage because less profitable companies provide lower shareholder 
Table 2. Test of the Determinants of Optimal Leverage Ratio.

\begin{tabular}{|c|c|c|c|}
\hline & (1) & $(2)$ & (3) \\
\hline & Full Sample & Year 2000-2006 & Year 2007-2011 \\
\hline \multirow[t]{2}{*}{ Firm Size (Size) } & $0.029^{* * *}$ & $0.023^{* * *}$ & $0.032^{\star * *}$ \\
\hline & $(0.00)$ & $(0.00)$ & $(0.00)$ \\
\hline \multirow[t]{2}{*}{ Profitability (Prof) } & $0.031^{* *}$ & $0.031^{*}$ & -0.027 \\
\hline & $(0.01)$ & $(0.06)$ & $(0.15)$ \\
\hline \multirow[t]{2}{*}{ Growth Opportunity (Growth) } & $0.196^{* * *}$ & $0.199^{* * *}$ & $0.173^{* * *}$ \\
\hline & $(0.00)$ & $(0.00)$ & $(0.00)$ \\
\hline \multirow[t]{2}{*}{ Tangibility (Tang) } & $0.087^{* * *}$ & $0.062^{* * *}$ & $0.144^{* * *}$ \\
\hline & $(0.00)$ & $(0.00)$ & $(0.00)$ \\
\hline \multirow[t]{2}{*}{ Non-Debt Tax Shields (NOT) } & $-0.729^{* * *}$ & $-0.674^{* * *}$ & $-0.630^{* * *}$ \\
\hline & $(0.00)$ & $(0.00)$ & $(0.00)$ \\
\hline \multirow[t]{2}{*}{ Ownership } & $0.015^{\star * *}$ & -0.000 & $0.017^{\star * *}$ \\
\hline & $(0.00)$ & $(0.99)$ & $(0.01)$ \\
\hline \multirow[t]{2}{*}{ Cons } & $-0.672^{* * *}$ & $-0.538^{\star * \star}$ & $-0.758^{* * *}$ \\
\hline & $(0.00)$ & $(0.00)$ & $(0.00)$ \\
\hline F-test & 0.00 & 0.00 & 0.00 \\
\hline $\mathrm{r} 2$ & 0.21 & 0.15 & 0.25 \\
\hline $\mathrm{N}$ & 12132 & 7030 & 5102 \\
\hline
\end{tabular}

Note: Standard Errors are reported in parentheses below the coefficients. Superscripts ${ }^{*},{ }^{* *}$, and ${ }^{* *}$ indicate significance at $10 \%, 5 \%$, and $1 \%$ levels, respectively.

returns, and increased leverage increases the bankruptcy risk. In contrast, the pecking order theory predict a negative relation between profitability and leverage. More profitable companies have more cash flows and therefore use less debt and have smaller leverage. Our results show a significant positive relation for Full sample and the Pre-reform subsample, a negative but insignificant relation for the Post-reform subsample.

Growth opportunity: The trade-off theory predicts a negative relationship between debt and growth opportunity because growth firms face more severe underinvestment and overinvestment issues and hence use less debt. Stakeholders of high growth firms are more likely to invest in value-decreasing projects to shift risks to creditors, making debt more costly. However, a positive relation is also documented by previous literature. [38] argued that leverage was negatively related to growth opportunities only for firms whose growth opportunities were not recognized by the capital market. Our results indicate a statistically significant positive relationship between growth and leverage, which is consistent with the well-documented evidence for Chinese firms. For example, [5] found growth potential proxied by the Market to Book ratio is positively related to debt ratio in China. [6] and [32] used the percentage change of total assets and sales growth 
rate as a proxy for growth respectively and find similar results.

Collateral (Tangibility): We find that the collateral value of assets and leverage have a significant positive relationship ( 0.087 for the full sample, 0.062 for the period of 2000-2006, and 0.144 for the period of 2007-2011). The trade-off theory suggests that firms with more tangible assets face lower financial stress costs, and therefore tend to use more debt. Tangible assets can be used as collateral to avoid the asset substitution problem, leading to lower agency costs of debt. Empirically, this is also consistent with the Chinese evidence.

State Ownership: Ownership structure is one of the most significant institutional differences between China and the Western countries. Most of the Chinese listed companies now are still under the control of the state and face great intervention by the government. [39] predicted that ownership structure may impact capital structure because agency costs could be minimized by the optimal structure of leverage and ownership. We document a positive relationship between state ownership and leverage (0.015) in the full sample. That is, firms with more non-circulating shares tend to have higher leverage ratio, which is consistent with the findings in [6]. However, this positive relationship is only observed in year 2007 to 2011 while the first period sample documents an insignificant negative coefficient.

To summarize, the empirical results suggest that firm size, growth opportunities, profitability, ownership, and tangibility are positively related to leverage, while non-debt tax shields are negatively related to leverage. This conclusion suggests that the estimation coefficients on the variables of profitability, firm size, and tangibility, and non-debt tax shields are largely consistent with the explanations of trade-off theory, but not with the pecking order theory.

\section{Testing the Partial Adjustment Model}

[1] [8], and [40] proposed that the presence of adjustment costs ${ }^{7}$ may restrict the firms' ability to jump to their target capital structure immediately and thus, firms may have to make a gradual adjustment toward the optimal/target level.

The speed of the target leverage adjustment depends on the tradeoff between the costs of adjusting leverage and the benefits of moving back towards the optimal level (i.e., the costs of being far from the optimal leverage level). The partial adjustment theory acknowledges that the firms' leverage ratio is not always equal to the optimal level. Instead, this theory suggests that firms will not make leverage adjustments if the benefit of moving toward the target level is not big enough to cover the adjustment costs. We follow the spirit of previous research (see, e.g., [19]) and employ a partial adjustment model of leverage to test the prediction of the trade-off theory.

${ }^{7}$ Leverage adjustment costs are the costs that may occur when firms choose between equity financing and debt financing. Those cost may include related legal fees, registration fees, taxes, accounting \& printing costs, and other fees paid to the market dealers for placing the equity/bond issue ([41] [42] [43] and [44]). 


$$
\Delta D e b t_{i t}=\alpha+\gamma D E F_{i t}+\beta D T L R_{i t}+\varepsilon_{i t}
$$

where $D E F_{i t}=$ Dividend payment for period $t+$ Capital expenditure for period $t$ + net increase in working capital for period $t+$ current portion of long-term debt at start of period $t$-Operating cash flows (after interest and taxes) for period t. $D T L R_{i t}=$ a firm's target leverage ratio at time $t\left(D_{e b t}^{*}\right)-$ its actual leverage ratio at time $t-1\left(D e b t_{i t-1}\right)$. The target leverage ratio is not observable and we follow the previous literature and use the predicted fitted values from the static model (1) as a proxy. In other words, a two-stage estimation procedure is used to test the partial adjustment theory. On the first stage regression we estimate the target leverage regression of model (1); On the second stage we run the partial adjustment model (2) by employing the fitted values from the first stage regression as a measure of the target leverage ratio $\left(D_{e b t}{ }_{i t}^{*}\right)$. The coefficient $\beta$ captures the adjustment speed that reflects how quickly a firm switches its debt ratio to the optimal/target level. As argued by [3] and [9], the adjustment speed will range from 0 to 1 if positive adjustment costs are involved. A small coefficient would suggest large adjustment costs for the firm and therefore, it will not be able to adjust toward its desire leverage level quickly, vice versus. When the coefficient is 1 , the firm makes the adjustment instantaneously.

To jointly test the pecking order and trade-off theories, we also add the financing deficit variable (DEF) in model (2). We predict that firms' capital structure is more consistent with pecking order theory than with trade-off theory if the coefficient on the DTLR is insignificant while the coefficient on DEF to 1 and the intercept equals to 0 .

To run the regression of model (2) we employ three econometric estimators: fixed effect model, [45]'s difference GMM, and [46]'s system GMM. For the GMM estimators, we use Arellano and Bond's AR2 test and the Hansen test ${ }^{8}$ to assess the validity of instruments used in the model specification. The rejection of the AR2 test suggests evidence of second autocorrelation. Thus, instruments used in estimation are not appropriate. If the Hansen test is rejected, the GMM estimated results may be associated with over-identification issues and hence we should interpret the results with caution.

The empirical results are reported in Table 3. Panels A, B, and C report the results for the Full, Pre-reform, and the Post-reform samples, respectively. As shown in Panel A of Table 3, the Arellano and Bond's AR2 test and Hansen's test all suggest that our dynamic panel data regression is well specified for the full sample. We find that the adjustment coefficients are significantly positive, which is consistent with the trade-off theory's prediction.

The difference GMM and system GMM estimates provide very similar adjustment coefficients while the fixed effect estimate is the largest. In economic terms, Chinese public firms adjust their leverage ratio toward the desired level at a speed ranging between 0.22 and 0.32 . [8] regarded coefficient of 0.30 or above as fast adjustment speeds. Therefore, our estimated adjustment speed indicates

${ }^{9}$ See, e.g., [47] [48] and [49]. 
Table 3. Test of the Partial Adjustment Model.

\begin{tabular}{|c|c|c|c|c|c|c|}
\hline \multicolumn{7}{|c|}{ Panel A: Full Sample } \\
\hline & (1) & $(2)$ & (3) & (4) & $(5)$ & (6) \\
\hline \multirow[t]{2}{*}{ DEF } & & & & $0.130^{* * *}$ & $0.164^{* * *}$ & $0.160^{* * *}$ \\
\hline & & & & $(0.003)$ & $(0.031)$ & $(0.038)$ \\
\hline \multirow[t]{2}{*}{ DTLR } & $0.507^{\star * *}$ & $0.510^{* * *}$ & $0.310^{* * *}$ & $0.466^{* * *}$ & $0.456^{* * *}$ & $0.268^{* * *}$ \\
\hline & $(0.008)$ & $(0.067)$ & $(0.056)$ & $(0.008)$ & $(0.067)$ & $(0.053)$ \\
\hline \multirow[t]{2}{*}{ Cons } & -0.001 & & $-0.149^{* *}$ & $-0.004^{* * *}$ & & -0.103 \\
\hline & $(0.002)$ & & $(0.071)$ & $(0.002)$ & & $(0.073)$ \\
\hline Estimators & FE & DGMM & SGMM & $\mathrm{FE}$ & DGMM & SGMM \\
\hline AR2 & & 0.78 & 0.87 & & 0.73 & 0.94 \\
\hline Sargan test & & 0.86 & 0.80 & & 0.99 & 1.00 \\
\hline Hansen test & & 0.06 & 0.37 & & 0.23 & 0.47 \\
\hline T-test & & & & 0.00 & 0.00 & 0.00 \\
\hline r2 & 0.29 & & & 0.38 & & \\
\hline $\mathrm{N}$ & 11075 & 9858 & 11075 & 11075 & 9858 & 11075 \\
\hline \multicolumn{7}{|c|}{ Panel B: Year 2000-2006 } \\
\hline & (1) & (2) & (3) & (4) & (5) & (6) \\
\hline \multirow[t]{2}{*}{ DEF } & & & & $0.118^{* * *}$ & 0.175 & 0.188 \\
\hline & & & & $(0.005)$ & $(0.127)$ & $(0.132)$ \\
\hline \multirow[t]{2}{*}{ DTLR } & $0.655^{\star * *}$ & $0.275^{\star}$ & $0.311^{* *}$ & $0.601^{* * *}$ & 0.186 & 0.207 \\
\hline & $(0.012)$ & $(0.144)$ & $(0.124)$ & $(0.012)$ & $(0.175)$ & $(0.174)$ \\
\hline \multirow[t]{2}{*}{ cons } & 0.001 & & 0.296 & $0.003^{* *}$ & & 0.302 \\
\hline & $(0.001)$ & & $(0.524)$ & $(0.001)$ & & $(0.447)$ \\
\hline Estimators & FE & DGMM & SGMM & FE & DGMM & SGMM \\
\hline AR2 & & 0.67 & 0.34 & & 0.94 & 0.45 \\
\hline Sargan test & & 0.69 & 0.82 & & 0.69 & 0.82 \\
\hline Hansen test & & 0.29 & 0.51 & & 0.21 & 0.41 \\
\hline $\mathrm{T}$ test & & & & 0.00 & 0.00 & 0.00 \\
\hline $\mathrm{r} 2$ & 0.38 & & & 0.45 & & \\
\hline $\mathrm{N}$ & 5973 & 4861 & 5973 & 5973 & 4861 & 5973 \\
\hline \multicolumn{7}{|c|}{ Panel C: Year 2007-2011 } \\
\hline & (7) & $(8)$ & (9) & $(10)$ & $(11)$ & $(12)$ \\
\hline \multirow[t]{2}{*}{ DEF } & & & & $0.117^{\star * *}$ & $0.178^{\star * *}$ & $0.234^{* *}$ \\
\hline & & & & $(0.005)$ & $(0.033)$ & $(0.115)$ \\
\hline \multirow[t]{2}{*}{ DTLR } & $0.711^{\star * *}$ & $0.431^{* * *}$ & $0.431^{* * *}$ & $0.653^{\star * *}$ & $0.498^{\star * *}$ & $0.457^{* * *}$ \\
\hline & $(0.013)$ & $(0.090)$ & $(0.093)$ & $(0.013)$ & $(0.072)$ & $(0.094)$ \\
\hline Cons & -0.001 & & -0.187 & $-0.004^{* *}$ & & -0.415 \\
\hline
\end{tabular}




\section{Continued}

\begin{tabular}{ccccccc}
\hline & $(0.002)$ & & $(0.298)$ & $(0.002)$ & & $(0.502)$ \\
Estimators & FE & DGMM & SGMM & FE & DGMM & SGMM \\
AR2 & & 0.15 & 0.07 & & 0.07 & 0.58 \\
Sargan test & & 0.04 & 0.03 & & 0.00 & 0.03 \\
Hansen test & & 0.29 & 0.34 & & 0.22 & 0.15 \\
T test & & & & 0.00 & 0.00 & 0.00 \\
r2 & 0.41 & & & 0.48 & & \\
N & 5102 & 4997 & 5102 & 5102 & 4997 & 5102 \\
\hline
\end{tabular}

Note: $\Delta D e b t_{i t}$ is defined as the amount of total debt issued by firm $i$ at year $t$, i.e. $\Delta D e b t_{i t}=D e b t_{i t}-D e b t_{i t-1}$; $D E F_{i t}$ is the financing deficit for firm $i$ at year $t . D T L R_{i t}$ is defined as the difference between a firm's target leverage ratio at time $t\left(D_{e b t_{i t}^{*}}\right)$ and its actual leverage ratio at time $t-1\left(D_{e b t_{i t-1}}\right)$. It measures the deviation from the target leverage ratio. The target leverage ratio is unobservable and it is proxied by the predicted fitted values from the static model. Standard Errors are reported in parentheses below the coefficients. Superscripts ${ }^{*}{ }^{* *}$, and ${ }^{* *}$ indicate significance at $10 \%, 5 \%$, and $1 \%$ levels, respectively.

that Chinese public firms have a target leverage ratio and they quickly adjust their actual leverages to their target levels. Assuming that the speed of adjustment is constant, this result implies that it takes less than two years for Chinese firms to adjust half of the deviation of the actual leverage ratio from the target leverage ratio. This adjustment speed is roughly two times faster than the evidence documented in the previous literature on China's capital structure. For instance, [4] examined a sample of Chinese public firms over the period between 1999 and 2004 by using a one-stage procedure to estimate the partial adjustment model and report the speed of adjustment of $18.5 \%$ per year for the leverage ratio. 9 . However, compared to previous studies on developed markets, we find that Chinese firms have relatively low speeds of leverage adjustment during our sample period. For example, [11] showed that European firms (including French, German, and UK) have considerably faster speeds of leverage adjustment in the range of 0.425 - 0.517. Similar results are also observed on US firms, with adjustment speeds ranging between 0.25 - 0.557 (see, [3] [8] [50], etc.).

Including the financial deficit variable in Model (2), as shown in Columns (4)-(6) of Table 3, we find that the leverage adjustment coefficients remain statistically and economically significant, ranging between 0.268 and 0.466 . The financing deficit coefficients are also quite similar to those obtained from the stand-alone pecking order mode ${ }^{10}$, varying between 0.130 and 0.164 . They are significantly positive but statistically and economically different from one. This suggests that Chinese firms make active leverage adjustment towards the target level but they finance their financial deficit mainly by equity. Overall, nesting the pecking order and target adjustment models in the same regression does not substantially impact the magnitude and the significance of the speed coefficient

\footnotetext{
${ }^{9[4]}$ substituted (3) into (2) and estimate the resulting model in one stage.

${ }^{10}$ For the sake of brevity, we do not present results for the stand-alone pecking order model. However, these are available upon request.
} 
and the deficit coefficient. Hence, the trade-off theory explains Chinese firms' capital structure better than the pecking-order theory.

Next we examine the results of two subsample periods as shown in Panel B and Panel C. The GMM specifications for the Pre-reform subsample passed the Arellano and Bond's AR2 test, Sargan's test and Hansen's test, while the GMM specifications for the Post-reform subsample passed the Arellano and Bond's AR2 test, and Hansen's test, but not Sargan's test. The financing deficit coefficients are similar in magnitude for the two subsample periods, although the two GMM estimators are statistically insignificant for the Pre-reform sample, but significant for the Post-reform subsample. The notable differences are for the leverage adjustment coefficients. The leverage adjustment coefficients for the Pre-reform subsample are smaller than those for the Full sample and no longer significant even at the $5 \%$ level for three of the model specifications as shown in columns (2), (5) and (6). On the contrary, the leverage adjustment coefficients for the Post-reform subsample for all model specifications are larger than those for the Full sample, indicating that the results of the partial adjustment for the full sample are mainly driven by the Post-reform period. The coefficients for the Post-reform subsample are larger than those for the Pre-reform subsample in almost all six specifications. For example, the difference GMM estimator presents that the leverage adjustment coefficient is 0.186 (insignificant at 10\%) for the Pre-reform subsample and is 0.498 (significant at $1 \%$ ) for the Post-reform. Similarly, the system GMM model predicts that the leverage adjustment coefficient is 0.207 (insignificant at $10 \%$ ) for the Pre-reform subsample and is 0.457 (significant at $1 \%)$ for the Post-reform subsample.

The empirical results so far suggest that the speed of adjustment in the pre-reform period is quite consistent with the findings in [4] and [7] from the perspective of economic interpretation. However, Chinese companies adjust to their target leverage much faster after the 2006 structural reform since the adjustment speed is inversely related to transaction costs. [4] attributed the findings of slow adjustment during the period between 1999 and 2004 to relatively large transaction costs that firms face when they borrow from banks, which in turn result in higher agency costs between shareholders and creditors.

Similarly, the higher coefficients we observe in the Post-reform subsample period from 2007 to 2011 indicate that the cost of adjustment to target leverage for Chinese firms substantially declines after 2007. This might be possible for Chinese firms because China started its currency reform in 2005 and split-share reforms in 2006. On one hand, reform of China's forex system with the measures that have been taken to improve the investment environment (i.e. the introduction of the qualified foreign institutional investor ("QFII") program) attracts more foreign capitals into Chinese equity and bond markets. On the other hand, the split-share reforms open up the door to China's secondary privatization, making it easier and cheaper for firms to obtain funding from the primary equity market. Further, these reforms reduce agency conflicts between controlling 
shareholders and minority shareholders in Chinese state-owned enterprises [51]. Shareholders have more incentives to monitor behaviors of managers, and to ensure that they maximize shareholders' value. All these reforms reduce transaction costs of issuing both equity and debt and hence provide business managers more impetus to make a fast adjustment toward their optimal leverage ratio.

Nevertheless, the above standard partial adjustment model simply suggests that there is no distinction between under leveraging (below-target leverage ratio) and overleveraging (above-target leverage ratio) firms. Instead, firms make a symmetric leverage adjustment toward the target level. However, it is important to notice that the benefits of increasing and decreasing leverage as well as the adjustment costs of moving toward the target levels may not necessarily be symmetrical, and hence, any leverage adjustment toward the optimal level may occur at asymmetric rates. Given that, next we partition the standard partial leverage adjustment specification into cases with an over leverage situation and those with an under leverage situation.

$$
\begin{gathered}
\Delta D e b t_{i t}=a+\delta_{1} D T L R_{i t}^{\text {over }}+\delta_{2} D T L R_{i t}^{\text {under }}+\varepsilon_{i t} \\
D T L R_{i t}^{\text {over }}=D T L R_{i t} \text {, if } D e b t_{i t-1}>D e b t_{i t}^{*} ; \\
D T L R_{i t}^{\text {under }}=D T L R_{i t} \text {, if } \text { otherwise } D T L R_{i t}^{\text {over }}=0 \\
\text { Debt } t_{i t-1}<D e b t_{i t}^{*} ; \text { otherwise } D T L R_{i t}^{\text {below }}=0
\end{gathered}
$$

where $D L T R_{i t}^{\text {over }}$ captures positive deviation of overleveraged firm's actual leverage ratio away from its optimal/target level while $D L T R_{i t}^{\text {under }}$ captures negative deviation of the underleveraged firm's actual leverage ratio away from its optimal level. This modified partial leverage adjustment model allows for the speed of leverage adjustment to change based on whether the actual leverage ratio $\left(D e b t_{i t-1}\right)$ is smaller or bigger than its target level ( Debt $\left.t_{i t}^{*}\right) . \delta_{1}$ and $\delta_{2}$ are two speed adjustment coefficients and they measure how quickly firms make their leverage adjustment toward the target when they are overleveraged or underleveraged respectively. If $\delta_{2}$ is bigger than $\delta_{1}$, this may either indicate that the costs of being below the target leverage are larger than those of being above the target one or suggest that the adjustment costs of lowering debt ratio are larger than those of increasing debt ratio. Consequently, firms undertake the leverage adjustment much faster when they are overleveraged than when they are under leverage. A similar explanation applies when $\delta_{2}$ is smaller than $\delta_{1}$.

Table 4 presents the estimation results of Model (3). Column (1)-(3) and (4)-(6) report the results for the stand-alone trade-off model and the modified joint model that tests pecking order and trade-off theories, separately. Column (1) and (4) adopt the fixed effect estimator, Columns (2) and (5) use the difference GMM estimator, and Columns (3) and (6) adopt the system GMM estimator. For the Full sample as shown in Panel A, the adjustment coefficients $\delta_{1}$ and $\delta_{2}$ are statistically significant in all cases except for the system GMM where only $\delta_{1}$ is significant. There is no supporting evidence that the adjustment coefficient for leverage above the target is statistically different from that of the below target 
Table 4. Test of the modified partial adjustment model.

\begin{tabular}{|c|c|c|c|c|c|c|}
\hline \multicolumn{7}{|c|}{ Panel A: Full Sample } \\
\hline & (1) & (2) & (3) & $(4)$ & (5) & (6) \\
\hline \multirow[t]{2}{*}{ DEF } & & & & $0.130^{\star * *}$ & $0.164^{* * *}$ & $0.162^{\star * *}$ \\
\hline & & & & $(0.003)$ & $(0.031)$ & $(0.036)$ \\
\hline \multirow[t]{2}{*}{ DTLR $^{\text {Under }}$} & $0.524^{\star * \star}$ & $0.505^{\star * *}$ & 0.171 & $0.474^{\star * *}$ & $0.459^{* *}$ & 0.148 \\
\hline & $(0.019)$ & $(0.194)$ & $(0.201)$ & $(0.017)$ & $(0.186)$ & $(0.195)$ \\
\hline \multirow[t]{2}{*}{ DTLR $^{\text {Over }}$} & $0.498^{\star * *}$ & $0.512^{* * *}$ & $0.330^{* * *}$ & $0.462^{* * *}$ & $0.454^{* * *}$ & $0.308^{\star * *}$ \\
\hline & $(0.012)$ & $(0.091)$ & $(0.095)$ & $(0.011)$ & $(0.091)$ & $(0.091)$ \\
\hline \multirow[t]{2}{*}{ Cons } & -0.002 & & -0.118 & $-0.005^{* * *}$ & & -0.078 \\
\hline & $(0.002)$ & & $(0.075)$ & $(0.002)$ & & $(0.072)$ \\
\hline Estimators & $\mathrm{FE}$ & DGMM & SGMM & $\mathrm{FE}$ & DGMM & SGMM \\
\hline AR2 & & 0.78 & 0.57 & & 0.73 & 0.35 \\
\hline Sargan test & & 0.85 & 0.86 & & 0.99 & 1.00 \\
\hline Hansen test & & 0.07 & 0.42 & & 0.31 & 0.63 \\
\hline T-test & & & & 0.00 & 0.00 & 0.00 \\
\hline F-test & 0.31 & 0.98 & 0.56 & 0.60 & 0.98 & 0.55 \\
\hline $\mathrm{r} 2$ & 0.29 & & & 0.38 & & \\
\hline $\mathrm{N}$ & 11075 & 9858 & 11075 & 11075 & 9858 & 11075 \\
\hline \multicolumn{7}{|c|}{ Panel B: Year 2000-2006 } \\
\hline & (1) & (2) & (3) & $(4)$ & (5) & (6) \\
\hline \multirow[t]{2}{*}{ DEF } & & & & $0.118^{* * *}$ & 0.175 & 0.086 \\
\hline & & & & $(0.005)$ & $(0.124)$ & $(0.110)$ \\
\hline \multirow[t]{2}{*}{ DTLR $^{\text {Under }}$} & $0.672^{* * *}$ & -0.019 & -0.009 & $0.602^{* * *}$ & 0.192 & -0.289 \\
\hline & $(0.028)$ & $(0.685)$ & $(0.926)$ & $(0.026)$ & $(0.645)$ & $(0.767)$ \\
\hline \multirow[t]{2}{*}{$\mathrm{DTLR}^{\text {Over }}$} & $0.647^{\star * *}$ & $0.330^{*}$ & $0.350^{\star *}$ & $0.600^{* * *}$ & 0.185 & $0.315^{* *}$ \\
\hline & $(0.017)$ & $(0.179)$ & $(0.170)$ & $(0.016)$ & $(0.213)$ & $(0.143)$ \\
\hline \multirow[t]{2}{*}{ Cons } & -0.000 & & 0.373 & $0.003^{*}$ & & 0.396 \\
\hline & $(0.002)$ & & $(0.573)$ & $(0.002)$ & & $(0.541)$ \\
\hline Estimators & $\mathrm{FE}$ & DGMM & SGMM & $\mathrm{FE}$ & DGMM & SGMM \\
\hline AR2 & & 0.76 & 0.31 & & 0.94 & 0.42 \\
\hline Sargan test & & 0.51 & 0.58 & & 0.49 & 0.72 \\
\hline Hansen test & & 0.17 & 0.39 & & 0.14 & 0.37 \\
\hline T-test & & & & 0.00 & 0.00 & 0.00 \\
\hline F-test & 0.51 & 0.66 & 0.73 & 0.96 & 0.99 & 0.45 \\
\hline $\mathrm{r} 2$ & 0.38 & & & 0.45 & & \\
\hline $\mathrm{N}$ & 5973 & 4861 & 5973 & 5973 & 4861 & 5973 \\
\hline
\end{tabular}




\section{Continued}

Panel C: Year 2007-2011

(1)

(2)

\begin{abstract}
DEF
\end{abstract}

\begin{tabular}{|c|c|c|c|c|c|c|}
\hline & & & & $(0.005)$ & $(0.032)$ & $(0.040)$ \\
\hline \multirow[t]{2}{*}{$\mathrm{DTLR}^{\text {Under }}$} & $0.755^{\star * *}$ & $0.431^{* *}$ & 0.157 & $0.699^{* * *}$ & $0.428^{* *}$ & 0.283 \\
\hline & $(0.031)$ & $(0.208)$ & $(0.328)$ & $(0.029)$ & $(0.194)$ & $(0.226)$ \\
\hline \multirow[t]{2}{*}{ DTLR $^{\text {Over }}$} & $0.689^{* * *}$ & $0.601^{* * *}$ & $0.366^{* * *}$ & $0.631^{\star * *}$ & $0.526^{* * *}$ & $0.282^{* * *}$ \\
\hline & $(0.019)$ & $(0.103)$ & $(0.118)$ & $(0.018)$ & $(0.101)$ & (0.109) \\
\hline \multirow[t]{2}{*}{ Cons } & -0.002 & & $-0.166^{*}$ & $-0.005^{\star * *}$ & & -0.136 \\
\hline & $(0.002)$ & & $(0.096)$ & $(0.002)$ & & $(0.088)$ \\
\hline Estimators & FE & DGMM & SGMM & FE & DGMM & SGMM \\
\hline AR2 & & 0.19 & 0.60 & & 0.08 & 0.26 \\
\hline Sargan test & & 0.00 & 0.00 & & 0.00 & 0.00 \\
\hline Hansen test & & 0.06 & 0.22 & & 0.17 & 0.36 \\
\hline T-test & & & & 0.00 & 0.00 & 0.00 \\
\hline F-test & 0.11 & 0.52 & 0.62 & 0.08 & 0.70 & 1.00 \\
\hline $\mathrm{r} 2$ & 0.41 & & & 0.48 & & \\
\hline $\mathrm{N}$ & 5102 & 4997 & 5102 & 5102 & 4997 & 5102 \\
\hline
\end{tabular}

Note: $D T L R^{\text {Over }}$ represents the positive deviation of overleveraged firm's actual leverage ratio above its target. $D T L R^{\text {Under }}$ represents the negative deviation of overleveraged firm's actual leverage ratio above its target. Standard Errors are reported in parentheses below the coefficients. Superscripts ${ }^{*},{ }^{* *}$, and ${ }^{* *}$ indicate significance at $10 \%, 5 \%$, and $1 \%$ levels, respectively.

leverage, which suggests that Chinese firms adjust toward the target at a symmetrical rate. This is inconsistent with US findings by [52] who find that firms adjust its debt level toward the industry mean when it is above the mean while it is indifferent when the debt level is below the mean.

For the Pre-reform subsample shown in Panel B of Table $4, \delta_{1}$ is statistically significant in all cases except for column (5), the System GMM model, but $\delta_{2}$ are insignificant for both the difference GMM and the system GMM estimators as shown in the columns (2), (3), (5) and (6). The differences in the magnitudes are notable: $\delta_{1}=-0.33$ and $\delta_{2}=-0.019$ in column (2) and $\delta_{1}=0.315$ and $\delta_{2}=-0.289$ in column (2). The results indicate that Chinese companies adjust faster toward its target leverage when they are over-leveraged than when they are under-leveraged.

For the Post-reform subsample shown in Panel C of Table $4, \delta_{1}$ and $\delta_{2}$ are similar to the results in Panel A of Table 4 for the Full sample. However, comparing with the results from the Pre-reform subsample, we find that both $\delta_{1}$ and $\delta_{2}$ are larger than those for the pre-reform subsample, suggesting that Chinese companies adjust toward their target leverage ratios faster after the 2006 reforms no matter whether they are underleveraged or overleveraged. 
Table 5. Test of the Error Correction Model for Full Sample.

\begin{tabular}{|c|c|c|c|c|c|c|}
\hline \multicolumn{7}{|c|}{ Panel A: Full Sample } \\
\hline & (1) & (2) & (3) & $(4)$ & $(5)$ & $(6)$ \\
\hline \multirow[t]{2}{*}{ DEF } & & & & $0.128^{\star * *}$ & $0.139^{* * *}$ & $0.118^{* * *}$ \\
\hline & & & & $(0.003)$ & $(0.022)$ & $(0.022)$ \\
\hline \multirow[t]{2}{*}{ CTLR } & $0.827^{\star * *}$ & $0.806^{* * *}$ & $0.693^{* * *}$ & $0.747^{\star * *}$ & $0.726^{* * *}$ & $0.560^{* * *}$ \\
\hline & $(0.022)$ & $(0.129)$ & $(0.119)$ & $(0.020)$ & $(0.117)$ & $(0.108)$ \\
\hline \multirow[t]{2}{*}{ LECT } & $-0.468^{* * *}$ & $-0.402^{\star * *}$ & $-0.394^{* * *}$ & $-0.434^{* * *}$ & $-0.371^{* * *}$ & $-0.365^{* * *}$ \\
\hline & $(0.008)$ & $(0.037)$ & $(0.034)$ & $(0.008)$ & $(0.035)$ & $(0.033)$ \\
\hline \multirow[t]{2}{*}{ Cons } & -0.002 & & -0.023 & $-0.005^{* * *}$ & & -0.015 \\
\hline & $(0.002)$ & & $(0.023)$ & $(0.002)$ & & $(0.022)$ \\
\hline Estimators & $\mathrm{FE}$ & DGMM & SGMM & $\mathrm{FE}$ & DGMM & SGMM \\
\hline AR2 & & 0.48 & 0.47 & & 0.94 & 0.37 \\
\hline Sargan test & & 0.10 & 1.00 & & 0.27 & 1.00 \\
\hline Hansen test & & 0.40 & 0.20 & & 0.22 & 0.10 \\
\hline T-test & & & & 0.00 & 0.00 & 0.00 \\
\hline F-test & 0.00 & 0.00 & 0.01 & 0.00 & 0.00 & 0.07 \\
\hline $\mathrm{r} 2$ & 0.31 & & & 0.39 & & \\
\hline $\mathrm{N}$ & 11075 & 9858 & 11075 & 11075 & 9858 & 11075 \\
\hline \multicolumn{7}{|c|}{ Panel B: Year 2000-2006 } \\
\hline & (1) & (2) & (3) & $(4)$ & (5) & (6) \\
\hline \multirow[t]{2}{*}{ DEF } & & & & $0.116^{* * *}$ & 0.099 & 0.041 \\
\hline & & & & $(0.005)$ & $(0.091)$ & $(0.090)$ \\
\hline \multirow[t]{2}{*}{ CTLR } & $0.826^{\star * *}$ & 0.086 & 0.409 & $0.739^{\star * *}$ & -0.048 & 0.253 \\
\hline & $(0.027)$ & $(0.655)$ & $(0.498)$ & $(0.026)$ & $(0.629)$ & $(0.418)$ \\
\hline \multirow[t]{2}{*}{ LECT } & $-0.625^{\star * *}$ & $-0.435^{* * *}$ & $-0.430^{* * *}$ & $-0.577^{* * *}$ & $-0.405^{\star \star}$ & $-0.423^{* * *}$ \\
\hline & $(0.013)$ & $(0.156)$ & $(0.134)$ & $(0.012)$ & $(0.162)$ & $(0.138)$ \\
\hline \multirow[t]{2}{*}{ Cons } & 0.000 & & 0.142 & $0.003^{\star *}$ & & 0.142 \\
\hline & $(0.001)$ & & $(0.098)$ & $(0.001)$ & & $(0.096)$ \\
\hline Estimators & $\mathrm{FE}$ & DGMM & SGMM & $\mathrm{FE}$ & DGMM & SGMM \\
\hline $\mathrm{AR} 2$ & & 0.25 & 0.71 & & 0.43 & 0.61 \\
\hline Sargan test & & 0.77 & 1.00 & & 0.73 & 1.00 \\
\hline Hansen test & & 0.52 & 0.52 & & 0.38 & 0.44 \\
\hline T-test & & & & 0.00 & 0.00 & 0.00 \\
\hline F-test & 0.00 & 0.62 & 0.97 & 0.00 & 0.50 & 0.70 \\
\hline $\mathrm{r} 2$ & 0.38 & & & 0.46 & & \\
\hline $\mathrm{N}$ & 5973 & 4861 & 5973 & 5973 & 4861 & 5973 \\
\hline \multicolumn{7}{|c|}{ Panel C: Year 2007-2011 } \\
\hline & (7) & (8) & (9) & $(10)$ & (11) & $(12)$ \\
\hline \multirow[t]{2}{*}{ DEF } & & & & $0.117^{\star * *}$ & $0.140^{\star * *}$ & $0.139^{* * *}$ \\
\hline & & & & $(0.005)$ & $(0.022)$ & $(0.025)$ \\
\hline
\end{tabular}




\section{Continued}

\begin{tabular}{|c|c|c|c|c|c|c|}
\hline \multirow[t]{2}{*}{ CTLR } & $0.855^{\star * *}$ & $0.907^{\star * *}$ & $0.756^{\star * *}$ & $0.797^{\star * *}$ & $0.807^{\star * \star}$ & $0.750^{\star * \star}$ \\
\hline & $(0.035)$ & $(0.125)$ & $(0.119)$ & $(0.033)$ & $(0.119)$ & $(0.115)$ \\
\hline \multirow[t]{2}{*}{ LECT } & $-0.688^{\star * *}$ & $-0.480^{* * *}$ & $-0.453^{* * *}$ & $-0.630^{\star * \star}$ & $-0.444^{\star * \star}$ & $-0.394^{\star * *}$ \\
\hline & $(0.014)$ & $(0.038)$ & $(0.037)$ & $(0.014)$ & $(0.037)$ & $(0.040)$ \\
\hline \multirow[t]{2}{*}{ Cons } & -0.001 & & -0.024 & $-0.004^{\star * *}$ & & -0.025 \\
\hline & $(0.002)$ & & $(0.026)$ & $(0.002)$ & & $(0.028)$ \\
\hline Estimators & $\mathrm{FE}$ & DGMM & SGMM & $\mathrm{FE}$ & DGMM & SGMM \\
\hline AR2 & & 0.18 & 0.22 & & 0.18 & 0.12 \\
\hline Sargan test & & 0.00 & 0.00 & & 0.00 & 0.00 \\
\hline Hansen test & & 0.18 & 0.18 & & 0.09 & 0.07 \\
\hline T-test & & & & 0.00 & 0.00 & 0.00 \\
\hline F-test & 0.00 & 0.00 & 0.01 & 0.00 & 0.00 & 0.00 \\
\hline $\mathrm{r} 2$ & 0.42 & & & 0.48 & & \\
\hline $\mathrm{N}$ & 5102 & 4997 & 5102 & 5102 & 4997 & 4092 \\
\hline \multicolumn{7}{|c|}{ Panel D: Full Sample With Reform Dummy } \\
\hline & (1) & (2) & (3) & (4) & (5) & (6) \\
\hline \multirow[t]{2}{*}{ DEF } & & & & $0.127^{\star * *}$ & $0.141^{\star * *}$ & $0.172^{\star * *}$ \\
\hline & & & & $(0.003)$ & $(0.021)$ & $(0.023)$ \\
\hline \multirow[t]{2}{*}{ CTLR } & $0.795^{* * *}$ & 0.215 & 0.307 & $0.711^{* * *}$ & -0.003 & -0.277 \\
\hline & $(0.029)$ & $(0.557)$ & $(0.399)$ & $(0.028)$ & $(0.541)$ & $(0.380)$ \\
\hline \multirow[t]{2}{*}{ LECT } & $-0.417^{\star * *}$ & $-0.334^{* * *}$ & $-0.478^{\star * *}$ & $-0.390^{* * *}$ & $-0.324^{\star *}$ & $-0.475^{\star \star *}$ \\
\hline & $(0.013)$ & $(0.130)$ & $(0.110)$ & $(0.012)$ & $(0.127)$ & $(0.110)$ \\
\hline \multirow[t]{2}{*}{ Post ${ }^{\star}$ CTLR } & 0.064 & 0.653 & 0.466 & $0.075^{*}$ & 0.795 & $0.899^{* *}$ \\
\hline & $(0.045)$ & $(0.546)$ & $(0.393)$ & $(0.042)$ & $(0.540)$ & $(0.386)$ \\
\hline \multirow[t]{2}{*}{ Post $^{*}$ LECT } & $-0.105^{\star * *}$ & -0.097 & $0.289^{* *}$ & $-0.089^{* * *}$ & -0.071 & $0.297^{\star \star}$ \\
\hline & $(0.020)$ & $(0.134)$ & $(0.122)$ & $(0.019)$ & $(0.131)$ & $(0.118)$ \\
\hline \multirow[t]{2}{*}{ Cons } & -0.002 & & -0.020 & $-0.005^{\star * *}$ & & -0.009 \\
\hline & $(0.002)$ & & $(0.028)$ & $(0.002)$ & & $(0.024)$ \\
\hline Estimators & FE & DGMM & SGMM & FE & DGMM & SGMM \\
\hline AR2 & & 0.24 & 0.39 & & 0.38 & 0.27 \\
\hline Sargan test & & 0.83 & 1.00 & & 0.99 & 1.00 \\
\hline Hansen test & & 0.38 & 0.16 & & 0.22 & 0.10 \\
\hline T-test & & & & 0.00 & 0.00 & 0.00 \\
\hline F-test & 0.00 & 0.82 & 0.87 & 0.00 & 0.53 & 0.18 \\
\hline $\mathrm{r} 2$ & 0.31 & & & 0.40 & & \\
\hline $\mathrm{N}$ & 11075 & 9858 & 11075 & 11075 & 9858 & 11075 \\
\hline
\end{tabular}

Note: $C T L R_{i t}=D e b t_{i t}^{*}-$ Debt $_{i t-1}^{*}$ is the change in the target debt ratio and its coefficient $\beta$ represents the short-run effect of the target debt ratio on actual debt ratio. $L E C T_{i t}=\operatorname{Debt}_{i t-1}-\gamma \operatorname{Debt}_{i t-1}^{*}$ is the leverage error correction term, which captures the deviation of actual leverage from the long-run target leverage ratio in the last accounting period. Standard Errors are reported in parentheses below the coefficients. Superscripts $^{*},{ }^{* *}$, and ${ }^{* *}$ indicate significance at $10 \%, 5 \%$, and $1 \%$ levels, respectively. 


\section{Testing the Error Correction Model}

In this section we also employ an Error Correction Model (ECM) to test whether the target/optimal leverage ratio has any long-run effect on the current leverage ratio. Noticeably, previous partial adjustment models suggest that the changes in the target leverage ratios have no impact on the costs of leverage adjustment. The error correction model allows to capture changes in the target leverage and their potential effects on the dynamic process of leverage adjustment. Both partial adjustment models and error correction models assume that the actual leverage ratios deviate from the target/optimal levels and firms make their leverage adjustment over time, but error correction models also control for the change in the target leverage ratios and meanwhile, allow for the examination of its short-run effect on the actual leverage ratio. We follow [11] and [14] and estimate the error correction model as:

$$
\Delta \operatorname{Debt}_{i t}=a+\beta C T L R_{i t}-\varphi L E C T_{i t}+\varepsilon_{i t}
$$

where $C T L R=\operatorname{Debt}_{i t}^{*}-\operatorname{Debt}_{i t-1}^{*}$ is the change in the target debt ratio and its coefficient $\beta$ represents the short-run effect of the target debt ratio on actual debt ratio. $L E C T_{i t}=D e b t_{i t-1}-\gamma D e b t_{i t-1}^{*}$. This is the leverage ratio error correction term, which represents the deviation of actual debt ratio away from the long run target level in the last fiscal year. The corresponding coefficient of $\varphi$ captures the long-term (equilibrium) effect of the target leverage ratio on the actual leverage ratio. Although [11] and [14] artificially assumed that the long-run coefficient equals to one, we believe that there may not be necessarily the case. Instead, we regress actual leverage ratio on target debt ratio in an effort to control the long-term relationship between actual leverage ratio and target leverage ratio. According to the Dickey-Fuller tests, we cannot reject that the residuals from this regression are stationary. In other words, the actual leverage ratios $\left(D e b t_{i t}\right)$ and target leverage ratios $\left(D e b t_{i t}^{*}\right.$ ) are co-integrated. Thus, we predict that there is a long-term (equilibrium) relationship between these two co-integrated variables. As a result, the coefficient of LECT captures the speed rates of the adjustment to the target leverage level.

The empirical results for the error correction model are reported in Table 5. Likewise, we employ the error correction models to examine the trade-off theory of Model (4) in Columns (1)-(3). We also include the financing deficit variables to Model (4) to jointly test the pecking-order and trade-off theories and the corresponding results are reported in Columns (4)-(6). Panel A, B, and C presents the empirical results of the error correction model for Full, Pre-reform, and Post-reform samples, respectively.

We first examine the results for the Full sample in Panel A. The AR2 test, the Sargan test, and the Hansen test are all rejected at the $10 \%$ significant level in the DGMM and SGMM estimators, suggesting that the GMM estimation models are satisfactory. We find that coefficients on CTLR and LECT are both at the $1 \%$ significant level. Significant positive coefficients on CTLR indicate the existence 
of short run effects of the target leverage ratio on actual leverage ratio. In other words, Chinese listed firms undertake swift short-run leverage adjustment toward their target levels in response to any changes in such target levels with the corresponding speed rates varying from 0.693 to 0.827 . On the contrary, the coefficients on leverage error correction term (LECT) range from 0.394 to 0.468 , indicating that Chinese listed firms also rapidly correct the past deviation of their actual leverage ratios from the long-term equilibrium level, with about $40 \%$ of the divergence narrowing in the following fiscal year. According to the F test, we also significantly reject the null hypothesis that there are no differences between the two speeds of adjustment $(\beta=\varphi)$. That is, Chinese listed firms adjust their leverage ratios toward the desired targets at asymmetric speed rates and they respond more rapidly to target leverage changes in the short run than to the deviation from the long-term target level in the last fiscal year. All these findings are consistent with those in the developed markets. For example, [14] observed that firms in UK, France, and Germany respond to the past divergence from target level with the adjustment speed ranging from 0.390 to 0.454 while their speeds of adjustment corresponding to target leverage changes appear to be more rapidly, ranging between 0.776 and 0.933 .

Columns (4)-(6) of Table 5 report the result of a modified version of Model (4) that is employed to jointly test both pecking-order and trade-off theories. We observe that the coefficients on CTLR and LECT marginally decrease in magnitudes but they remain economically and statistically significant. Furthermore, the coefficients on the financing deficit have similar magnitudes as those estimated for the stand-alone pecking order model ${ }^{11}$ and again, they are economically insignificant. Overall, the error correction model provides further support for the trade-off theory against the pecking order theory as Chinese firms make dynamic adjustment towards target leverage, with stronger and faster response to changes in target leverage than to past divergence from target leverage.

Compared with Pre-reform subsample shown in Panel B of Table 5, the coefficients on LECT for the Post-reform subsample in Panel C are comparable for all six estimators. However, the coefficients on CTLR are much larger for Post-reform subsample for all estimators. For example, the coefficient $\beta$ in column (6) is 0.253 for Pre-reform subsample and is 0.750 for Post-reform subsample. These results suggest that Chinese companies' leverage ratios respond to their target (optimal) leverage changes much more promptly after the split-share reform of 2006.

\section{Conclusions}

We examine the trade-off and pecking order theories of capital structure using various methodologies in Chinese listed firms. We find strong evidence that is consistent with the trade-off theory: Chinese companies dynamically adjust to

\footnotetext{
${ }^{11}$ For the sake of brevity, we do not present results for the stand-alone pecking order model. However, these are available upon request.
} 
their target leverage ratios. They adjust to their target leverage more rapidly when transactions costs are lower after the 2006 share structure reform. These results further support the applicability of dynamic partial adjustment models.

This study has four main contributions to the literature. First, we adopt the error correction model (ECM) in the empirical tests to examine the target adjustment theory of capital structure of companies in a transition economic. The ECM allows us to examine both the short-run adjustment dynamics towards the long-run target leverage ratio and the long-run relationship between the actual leverage ratios and the target leverage ratio. Second, we employ various econometric methods to estimate the regression models, i.e. fixed effect and the dynamic panel estimators (i.e. Difference GMM and System GMM) which may help reduce any bias that might result from the OLS estimation. Third, we not only examine the pecking-order and trade-off theories in isolation, but also nest the two theories in one single specification to examine one theory against the other for Chinese firms. Lastly, this is the first study to consider the impact of China's recent economic structure reform on firms' financing behavior. We find that Chinese firms adjust to target capital structure much faster in the Post-reform period than in the Pre-reform period. This result indirectly supports the dynamic trade-off theory as transaction costs are important factors affecting the speed of adjustment to target leve rage. Overall, our results suggest that the dynamic trade-off theory can better explain the financing behavior of Chinese companies than the pecking order theory.

\section{Acknowledgements}

We are enormously thankful for the hard work of Jing $\mathrm{Wu}$ and Zhou Yu from Renmin University of China for doing the groundwork for our empirical analysis.

\section{References}

[1] Grillo, G. and Myers, S.C. (1984) The Capital Structure Puzzle. The Journal of Finance, 39, 574-592. https://doi.org/10.1111/j.1540-6261.1984.tb03646.x

[2] Bradley, M., Jarrell, G.A. and Kim, E.H. (1984) On the Existence of an Optimal Capital Structure: Theory and Evidence. Journal of Finance, 39, 857-878. https://doi.org/10.1111/j.1540-6261.1984.tb03680.x

[3] Leary, M.T. and Roberts, M.R. (2005) Do Firms Rebalance Their Capital Structures? The Journal of Finance, 60, 2575-2619.

[4] Qian, Y., Yao, T. and Wirjanto, T.S. (2009) Do Chinese Publicly Listed Companies Adjust Their Capital Structure toward a Target Level? China Economic Review, 20, 662-676.

[5] Chen, J.J. (2004) Determinants of Capital Structure of Chinese-Listed Companies. Journal of Business Research, 57, 1341-1351. https://doi.org/10.1016/S0148-2963(03)00070-5

[6] Huang, G. and Song, F.M. (2006) The Determinants of Capital Structure: Evidence from China. China Economic Review, 17, 14-36. 
https://doi.org/10.1016/j.chieco.2005.02.007

[7] Qian, Y., Tian, Y. and Wirjanto, T.S. (2008) An Empirical Investigation into the Capital-Structure Determinants of Publicly Listed Chinese Companies: A Static Analysis. University of Waterloo, Waterloo.

[8] Flannery, M.J. and Rangan, K.P. (2006) Partial Adjustment toward Target Capital Structures. Journal of Financial Economics, 79, 469-506.

https://doi.org/10.1016/j.jfineco.2005.03.004

[9] Shyam-Sunder, L. and Myers, S.C. (1999) Testing Static Tradeoff against Pecking Order Models of Capital Structure. Journal of Financial Economics, 51, 219-244. https://doi.org/10.1016/S0304-405X(98)00051-8

[10] De Miguel, A. and Pindado, J. (2001) Determinants of Capital Structure: New Evidence from Spanish Panel Data. Journal of Corporate Finance, 7, 77-99. https://doi.org/10.1016/S0929-1199(00)00020-1

[11] Dang, V.A. (2013) Testing Capital Structure Theories using Error Correction Models: Evidence from the UK, France and Germany. Applied Economics, 45, 171-190. https://doi.org/10.1080/00036846.2011.597724

[12] Campello, M., Ribas, R. and Wang, A. (2012) Is the Stock Market Just a Side Show? Evidence from a Structural Reform. Working Paper 2012.

[13] Maddala (2001). Introduction to Econometrics. 3rd Edition, John Wiley and Sons, Hoboken.

[14] Dang, V.A. (2010) Testing the Trade-off and Pecking Order Theories: A Dynamic Panel Framework. Working Paper, Manchester Business School, Manchester.

[15] Campello, M., Ribas, R. and Wang, A. (2014) Is the Stock Market Just a Side Show? Evidence from a Structural Reform. Review of Corporate Finance Studies, 3, 1-38. https://doi.org/10.1093/rcfs/cfu006

[16] Liao, L., Liu, B. and Wang, H. (2014) China's Secondary Privatization: Perspectives from the Split-Share Structure Reform. Journal of Financial Economics, 113, 500-518. https://doi.org/10.1016/j.jfineco.2014.05.007

[17] Bekaert, G. and Harvey, C.R. (2000) Foreign Speculators and Emerging Equity Markets. The Journal of Finance, 55, 565-613.

https://doi.org/10.1111/0022-1082.00220

[18] Lemmon, M.L. and Zender, J.F. (2010) Debt Capacity and Tests of Capital Structure Theories. Journal of Financial and Quantitative Analysis, 45, 1161-1187. https://doi.org/10.1017/S0022109010000499

[19] Frank, M.Z. and Goyal, V.K. (2003) Testing the Pecking Order Theory of Capital Structure. Journal of Financial Economics, 67, 217-248. https://doi.org/10.1016/S0304-405X(02)00252-0

[20] Graham, J.R. and Harvey, C.R. (2001) The Theory and Practice of Corporate Finance: Evidence from the Field. Journal of Financial Economics, 60, 187-243. https://doi.org/10.1016/S0304-405X(01)00044-7

[21] Graham, J.R. (2000) How Big Are the Tax Benefits of Debt? The Journal of Finance, 55, 1901-1941.

[22] Welch, I. (2004) Capital Structure and Stock Returns. Journal of Political Economy, 112, 106-132. https://doi.org/10.1086/379933

[23] Huang, R. and Ritter, J.R. (2009) Testing Theories of Capital Structure and Estimating the Speed of Adjustment. Journal of Financial and Quantitative Analysis, 44, 237-271. https://doi.org/10.1017/S0022109009090152 
[24] Antoniou, A., Guney, Y. and Paudyal, K. (2008) The Determinants of Capital Structure: Capital Market-Oriented versus Bank-Oriented Institutions. Journal of Financial and Quantitative Analysis, 43, 59-92. https://doi.org/10.1017/S0022109000002751

[25] Faulkender, M., et al. (2012) Cash Flows and Leverage Adjustments. Journal of Financial Economics, 103, 632-646. https://doi.org/10.1016/j.jfineco.2011.10.013

[26] Booth, L., et al. (2001) Capital Structures in Developing Countries. The Journal of Finance, 56, 87-130. https://doi.org/10.1111/0022-1082.00320

[27] Seifert, B. and Gonenc, H. (2010) Pecking Order Behavior in Emerging Markets. Journal of International Financial Management \& Accounting, 21, 1-31. https://doi.org/10.1111/j.1467-646X.2009.01034.x

[28] Tong, G. and Green, C.J. (2005) Pecking Order or Trade-Off Hypothesis? Evidence on the Capital Structure of Chinese Companies. Applied Economics, 37, 2179-2189. https://doi.org/10.1080/00036840500319873

[29] Ni, J. and Yu, M. (2008) Testing the Pecking-Order Theory: Evidence from Chinese Listed Companies. Chinese Economy, 41, 97-113. https://doi.org/10.2753/CES1097-1475410105

[30] Lien, D., Lo, M. and Ni, J. (2012) Selective Asymmetric Capital Financing Behavior: Preference towards Equity Financing. Annals of Financial Economics, 7, 29 p. https://doi.org/10.1142/S2010495212500042

[31] Guo, L., Dai, Y. and Lien, D. (2017) The Effects of China's Split-Share Reform on Firms' Capital Structure Choice. Applied Economics, 48, 2530-2549. https://doi.org/10.1080/00036846.2017.1293792

[32] Titman, S. and Wessels, R. (1988) The Determinants of Capital Structure Choice. The Journal of Finance, 4, 1-19. https://doi.org/10.1111/j.1540-6261.1988.tb02585.x

[33] Kraus, A. and Litzenberger, R.H. (1973) A State-Reference Model of Optimal Financial Leverage. The Journal of Finance, 28, 911-922. https://doi.org/10.1111/j.1540-6261.1973.tb01415.x

[34] Scott, J. and James, H. (1976) A Theory of Optimal Capital Structure. The Bell Journal of Economics, 7, 33-54. https://doi.org/10.2307/3003189

[35] Kim, E.H. (1978) A Mean-Variance Theory of Optimal Capital Structure and Corporate Debt Capacity. The Journal of Finance, 33, 45-63. https://doi.org/10.1111/j.1540-6261.1978.tb03388.x

[36] Rajan, R.G. and Zingales, L. (1995) What Do We Know about Capital Structure? Some Evidence from International Data. The Journal of Finance, 50, 1421-1460. https://doi.org/10.1111/j.1540-6261.1995.tb05184.x

[37] Wald, J.K. (1999) How Firm Characteristics Affect Capital Structure: An International Comparison. Journal of Financial Research, 22, 161-187. https://doi.org/10.1111/j.1475-6803.1999.tb00721.x

[38] Lang, L.E., Ofek, E. and Stulz, R. (1996) Leverage, Investment and Firm Growth. Journal of Financial Economics, 40, 3-29. https://doi.org/10.1016/0304-405X(95)00842-3

[39] Jensen, M.C. and Meckling, W.H. (1976) Theory of the Firm: Managerial Behavior, Agency Cost and Ownership Structure. Journal of Financial Economics, 3, 305-360. https://doi.org/10.1016/0304-405X(76)90026-X

[40] Fischer, E.O., Heinkel, R. and Zechner, J. (1989) Dynamic Capital Structure Choice: Theory and Tests. The Journal of Finance, 44, 19-40.

https://doi.org/10.1111/j.1540-6261.1989.tb02402.x 
[41] Oliner, S. and Rudebusch, G. (1992) Source of the Financing Hierarchy for Business Investment. The Review of Economics and Statistics, 74, 643-654. https://doi.org/10.2307/2109378

[42] Bhanot, K. and Guo, L. (2011) Negative Credit Spreads: Liquidity and Limits to Arbitrage. The Journal of Fixed Income, 21, 32-41. https://doi.org/10.3905/jfi.2011.21.1.032

[43] Bhanot, K. and Guo, L. (2012) Types of Liquidity and Limits to Arbitrage-The Case of Credit Default Swaps. Journal of Futures Markets, 32, 301-329. https://doi.org/10.1002/fut.20518

[44] Guo, L. (2013) Determinants of Credit Spreads: The Role of Ambiguity and Information Uncertainty. The North American Journal of Economics and Finance, 24, 279-297. https://doi.org/10.1016/j.najef.2012.10.003

[45] Arellano, M. and Bond, S.R. (1991) Some Tests of Specification for Panel Data: Monte Carlo Evidence and an Application to Employment Equations. Review of Economic Studies, 58, 227-297. https://doi.org/10.2307/2297968

[46] Blundell, R.W. and Bond, S.R. (1998) Initial Conditions and Moment Restrictions in Dynamic Panel Data Models. Journal of Econometrics, 87, 115-143. https://doi.org/10.1016/S0304-4076(98)00009-8

[47] Roodman, D.M. (2009) How to Do xtabond2: An Introduction to Difference and System GMM in Stata. The Stata Journal, 9, 86-136.

[48] Guo, L. (2016) Are U.S. Investors Blindly Chasing Returns in Foreign Countries? International Review of Economics \& Finance, 41, 309-334. https://doi.org/10.1016/j.iref.2015.08.002

[49] Guo, L. and Lien, D. (2017) Uncertainty and Liquidity in Corporate Bond Market. Applied Economics, 49, 4760-4781. https://doi.org/10.1080/00036846.2017.1293792

[50] Jalilvand, A. and Harris, R.S. (1984) Corporate Behavior in Adjusting to Capital Structure and Dividend Targets: An Econometric Study. The Journal of Finance, 39, 127-145. https://doi.org/10.1111/j.1540-6261.1984.tb03864.x

[51] Yeh, Y.-H., et al. (2009) Non-Tradable Share Refrom and Corporate Governance in the Chinese Stock Market. Corporate Governance: An International Review, 17, 457-475. https://doi.org/10.1111/j.1467-8683.2009.00754.x

[52] Cai, F. and Ghosh, A. (2003) Tests of Capital Structure Theory: A Binomial Approach. Journal of Business and Economics Studies, 9, 20-32. 